JURNAL TEERNOSAINS

\title{
THERMAL CHANGES OBSERVED AT DRILLING SITE DURING BONE DRILLING: Model Studil in Bovine Rib
}

\author{
Dedy Kusuma \\ Department of Biomedical, Faculty of Dentistry \\ Gadjah Mada University, Yogyakarta, Indonesia \\ Email: dedykusuma.ugm@gmail.com
}

\begin{abstract}
ABSTRAK
Penggunaan bor tulang dalam proses odontectomy dan persiapan implan gigi dapat meningkatkan suhu di sekitar lubang pengeboran. Perubahan termal adalah pertanda penting untuk penyembuhan tulang secara fisiologis karena peningkatan suhu di atas ambang batas harus diminimalkan. Tujuan dari studi pemodelan ini adalah untuk membandingkan perubahan suhu yang dihasilkan selama pengeboran tulang dengan berbagai kecepatan. Delapan belas tulang rusuk sapi segar dipilih karena kesamaan sifat fisik dan dimensi rahang bawah manusia. Sebuah bor konstan dengan beban 4.06N diterapkan di seluruh prosedur pengeboran melalui tali pengeboran. Tulang rusuk sapi dibor dengan menggunakan bur geometry yang sama ( twist drill, 120 point angle) pada kecepatan rendah $(8,750$ rpm, 21,875 rpm, $35.000 \mathrm{rpm}$ ).

Perubahan suhu tulang yang dihasilkan oleh proses pengeboran diukur dengan thermocouple tipe-K. Kecepatan $8750 \mathrm{rpm}$ menghasilkan perubahan suhu maksimum di kedua jarak $1 \mathrm{~mm}$ dan $2 \mathrm{~mm}$ dari lubang pengeboran. Perubahan suhu minimal direkam untuk kecepatan $35.000 \mathrm{rpm}$. Tes ANOVA menunjukkan rata-rata perubahan termal untuk setiap kecepatan pada jarak 1 dan $2 \mathrm{~mm}$ dari lubang pengeboran berbeda secara signifikan. Manfaat klinis menggunakan kecepatan di bawah $35000 \mathrm{rpm}$ perlu dipertimbangkan karena berpotensi menimbulkan risiko kerusakan termal.
\end{abstract}

Kata kunci: kecepatan pengeboran, bur, geometry kerusakan termal, suhu tulang.

\begin{abstract}
The use of bone drill in the process of odontectomy and preparation of dental implant may increase temperature around drilling hole. As thermal changes are the critical precursor to physiological bone healing, increased of temperature over threshold must be minimized. The aim of this model study was to compare the temperature changes that were generated during bone drilling with various speeds. Eighteen fresh bovine ribs were chosen due to the similarity of physical properties and dimension of human mandible. A constant drill load of 4.06N was applied throughout the drilling procedures via a drilling rig. Bovine ribs were drilled by using the same bur geometry (twist drill, 120 point angle) at low speed (8.750 rpm, $21.875 \mathrm{rpm}, 35.000 \mathrm{rpm})$. The bone temperature changes generated by the drilling process were measured measured by K-type thermocouple. The speed of 8750 rpm produced a maximum temperature changes in both distance of $1 \mathrm{~mm}$ and $2 \mathrm{~mm}$ from drilling hole. Minimal temperature changes were recorded for the speed of $35.000 \mathrm{rpm}$. ANOVA test, showed the mean of thermal changes
\end{abstract}


for each of speed at distance 1 and $2 \mathrm{~mm}$ from drilling hole. The clinical benefits of using speed below 35000 rpm need to be considered due to the potential risk of thermal damage.

Key word: drilling speed, bur geometry, thermal damage, bone temperature.

\section{INTRODUCTION}

Heat generation is a common problem during any type of drilling particularly the drilling of bone. Bone is poor conductor, so that bone is more sensitive to damage due to heat elevation and the difficulty of conducting heat away from the cutting edge (Hillery and Shuaib, 1999). Important features which allow bone to withstand thermal damage are the relative water content (about 35\%) and the movement of fluid within living tissue (Leunig and Hertel, 1996). Drilling process on the bone will disturb the blood flow around the tissue due to occlusion of vessels by fat emboli and bone particulate debris, interruption of vessels and thermal injury in which may cause necrotic tissue and reducing the stability and strength of the implant fixation (Schemitsch et al., 1995).

Bone is a special type of connective tissue consisting of inter-cellular calcified material and comprises of organic and mineral phase (Hillery and Shuaib, 1999). Roughly one third of the weight of bone is contributed by collagen fibers. Cells account for only 2 percent of the mass of a typical bone and osteocytes are the most abundant. Generally the type of bone is divided into outer layer and inner layer. The outer layer is hard surface and called cortical bone and is covered by a membrane with a fibrous outer layer and a cellular inner layer called periosteum (Martini, 2006; Hillery and Shuaib, 1999). The inner spongous layer called cancellous bone has hollow geometry and contain bone marrow. This layer is also lined with a similar cell layer with osteogenic properties called endosteum (Hillery and Shuaib, 1999). Endosteum is an incomplete cellular layer which is active during bone growth, repair, and remodeling, covers the trabeculae of spongy bone and lines the inner surface of central canal (Martini, 2006).

The required speed, applied force, heat generation and bone damage are the main parameters to be considered when evaluating the drilling performance. Ohashi et al. (1994) define the factors which influence the drilling quality and need to be determined: the bur geometry and materials, the speed of rotation, the torque, the applied force, the use of irrigation, pre-drilling (i.e. drilling with a smaller diameter of bur before drilling with definitive diameter) and, finally the cortical thickness and bone density.

The thermal capacity and conductivity of bone constitutes other important factors affecting the temperature rise. The temperature developed within a second of bone tissue depends on heat diffusity (the ability of material to heats up) and thermal conductivity (the ability of material to transfer heat from a source). Unlike drilling metal, the temperature of the bone will raise more during the process due to its poor thermal capacity and conductivity, chips carrying away a smaller percentage of the heat (Karmani S, 2006)

Several evidences have given much attention on heat elevation during implant or surgery procedure. Many post operative complication cases in dental surgery have a similarity sign and symptom with the impaired bone healing due to thermal necrosis. In other side, direct evidence is still hard to find because during surgery procedure, the real temperature is not measured accurately.

Davidson and James (2003) recently reported that bur speed, feed rates, and bur diameter had the most significant impact on thermal changes. Many researchers suggested that bur speed should be kept under 2000 rpm the actual correlation between the actual bur speed and thermal injury has not been well established, because the studies relied on the manufacturer's claim of free running bur speed and it was not known whether those speeds were constant during drilling (Abouzgia et al., 1996). 


\section{Materials and Methods}

a. Preparation of bone sample

Eighteen fresh bovine ribs were chosen due to the similarity of physical properties and dimension with human mandible (Nam O., et al., 2006).

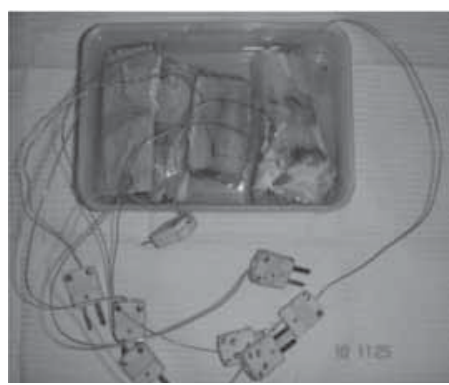

Figure 1.

Fresh bovine ribs

b. Measurement speed of the bur with motor system

The bur was inserted into the drilling machine connected with the electric portable motor system with variable control speed range between $0-35.000 \mathrm{rpm}$ (Hannessi, SDE-H30, Korea). In the clinical situation, the drilling is done either in low or high speed. Therefore in this research the speed was set up at 8,750 rpm (low speed) , 21,875 rpm and $35.000 \mathrm{rpm}$ (high speed). The drilling machine was fixated with adjustable clamp to minimize the vibration. Weight was placed on the platform to produce force $4.06 \mathrm{~N}$ (Figure 2).

c. Measurement of the temperature of bone The bone temperature was measured by K-type thermocouple (Omega Inc., USA) with accuracy in range -270 to $1370^{\circ} \mathrm{C}$. The thermocouple with diameter $0.1 \mathrm{~mm}$ was inserted into pre-drilled hole. Thermocouple was placed at a distance of 1 and $2 \mathrm{~mm}$ from the bur hole that was previously measured with sliding caliper. The depth of thermocouple's insertion was set at $3 \mathrm{~mm}$. The thermocouples were connected to an Omega Digital Thermometer. Initial temperature was recorded before drilling the bone.
Temperature increasing was recorded during bone was drilled at $6 \mathrm{~mm}$ distance with speed of each 8,750, 21,875, and $35.000 \mathrm{rpm}$. (Figure $3)$. For each speed, the recording was done in one hole in each sample.

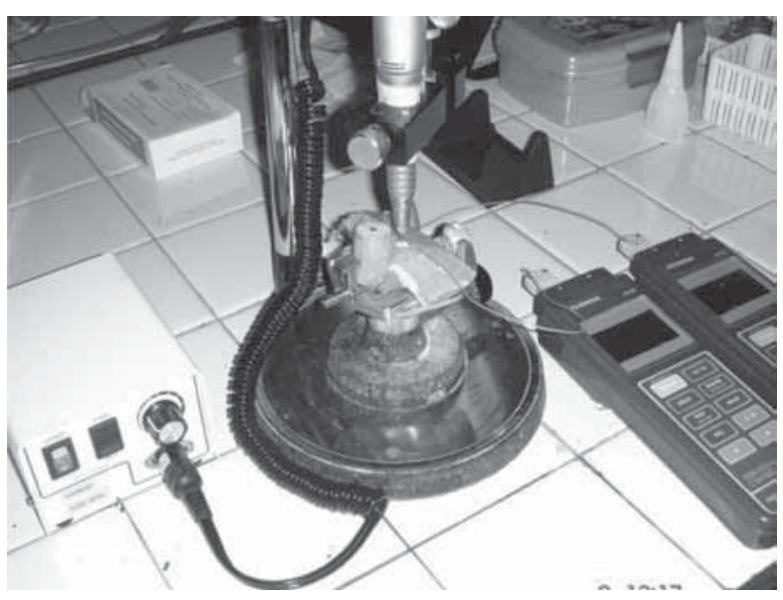

Figure 2.

Schematic of model study

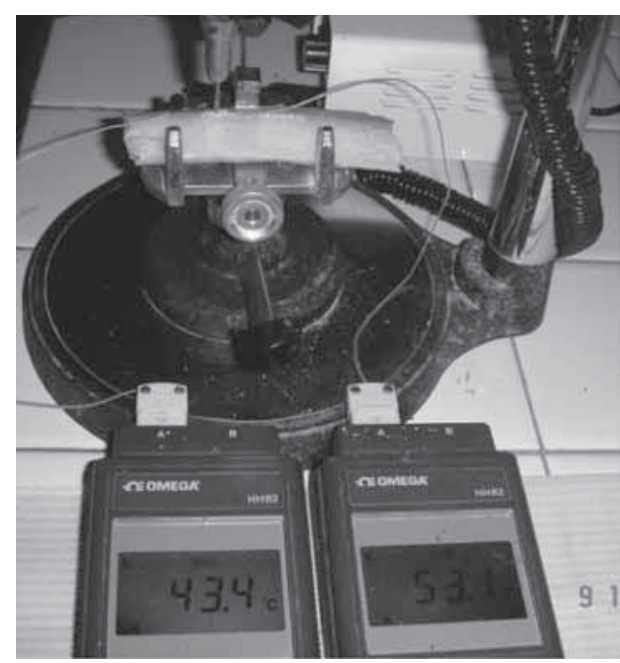

Figure 3.

Schematic drawing of thermal changes measurement

The research has been carried out at The Heat and Transfer Laboratory, Inter University Centre (IUC), School of Graduate, Gadjah Mada University, Yogyakarta, Indonesia. The data was analysed and using two-way analysis of variance (ANOVA). 


\section{RESULTS}

The mean and standard deviation of the bone temperature increase during drilling process at $1 \mathrm{~mm}$ and $2 \mathrm{~mm}$ from drill periphery were shown in table 1 . The average drilling time for speed 8,750, 21,875, and $35.000 \mathrm{rpm}$ was 12,2, 4,88 and 3,76 second, respectively.

Table 1

Mean of thermal changes during bone drilling $\left(\mathrm{C}^{\circ}\right)$

\begin{tabular}{|l|l|l|l|}
\hline \multirow{2}{*}{$\begin{array}{c}\text { Drill } \\
\text { periphery }\end{array}$} & \multicolumn{3}{|c|}{ Drilling speed } \\
\cline { 2 - 4 } & $\mathbf{8 . 7 5 0 ~ \mathbf { ~ r m }}$ & $\mathbf{2 1 . 8 7 5} \mathbf{~ r p m}$ & \multicolumn{1}{|c|}{$35.000 \mathbf{~ r p m}$} \\
\hline $1 \mathrm{~mm}$ & $30.93 \pm 8.63$ & $16.16 \pm 7.03$ & $12.30 \pm 5.95$ \\
\hline $2 \mathrm{~mm}$ & $9.36 \pm 2.37$ & $6.73 \pm 0.77$ & $6.60 \pm 1.27$ \\
\hline
\end{tabular}

Table 1 shows that the speed of $8750 \mathrm{rpm}$ produced maximum changes of temperature either at a distance of $1 \mathrm{~mm}$ and $2 \mathrm{~mm}$ from drilling hole. Minimal temperature changes were observed at speed $35.000 \mathrm{rpm}$ which resulted the delta temperature of $12,30^{\circ} \mathrm{C}$ and $6,60^{\circ} \mathrm{C}$, at 1 and $2 \mathrm{~mm}$ drill periphery, respectively.

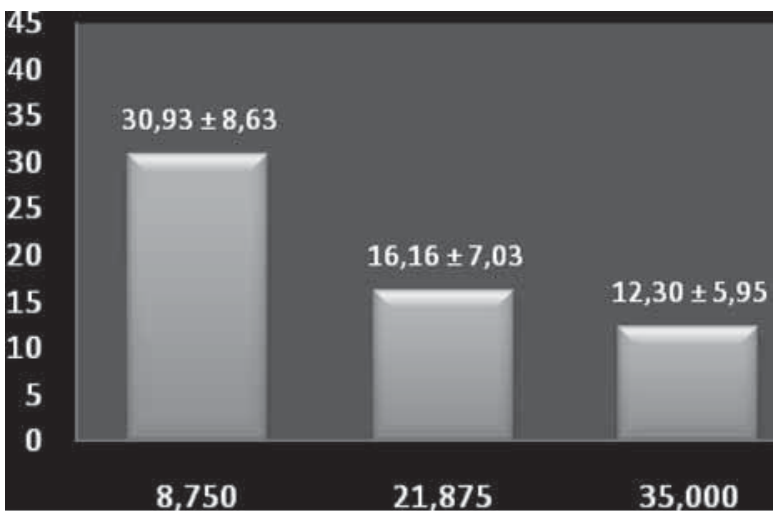

Graphic 1.

Pattern of thermal changes during bone drilling with various speeds $1 \mathrm{~mm}$ from drilling hole

The mean and standard deviation of thermal changes during bone drilling with various speed at $1 \mathrm{~mm}$ distance from drilling hole.

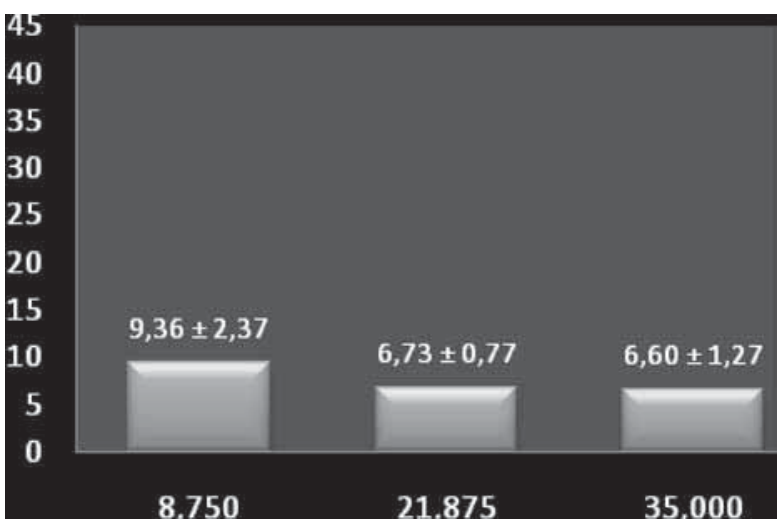

Graphic 2.

Pattern of thermal changes during bone drilling with various speeds $2 \mathrm{~mm}$ from drilling hole

The mean and standard deviation of thermal changes during bone drilling with various speed at $1 \mathrm{~mm}$ distance from drilling hole.

Graphic 1 and 2, show the pattern of thermal changes that tends to decrease with increasing of speed at a distance of $1 \mathrm{~mm}$ and $2 \mathrm{~mm}$ from drilling hole. This study used constant force $4,06 \mathrm{~N}$ and the same drilling deep $6 \mathrm{~mm}$ in all specimens.

Table 2.

The result of ANOVA Test

Tests of Between-Subjects Effects

Dependent Variable:thermal_changes

\begin{tabular}{|l|l|l|l|l|l|}
\hline Source & $\begin{array}{l}\text { Type III Sum } \\
\text { of Squares }\end{array}$ & df & $\begin{array}{l}\text { Mean } \\
\text { Square }\end{array}$ & F & Sig. \\
\hline $\begin{array}{l}\text { Corrected } \\
\text { Model }\end{array}$ & $1268.258^{\text {a }}$ & 5 & 253.652 & 9.092 & $.001^{*}$ \\
\hline Intercept & 3370.205 & 1 & 3370.205 & 120.808 & $.000^{*}$ \\
\hline speeds & 388.360 & 2 & 194.180 & 6.961 & $.010^{*}$ \\
\hline drill_periphery & 673.445 & 1 & 673.445 & 24.140 & $.000^{*}$ \\
\hline $\begin{array}{l}\text { speeds*drill_ } \\
\text { periphery }\end{array}$ & 206.453 & 2 & 103.227 & 3.700 & .056 \\
\hline Error & 334.767 & 12 & 27.897 & & \\
\hline Total & 4973.230 & 18 & & & \\
\hline Corrected Total & 1603.025 & 17 & & & \\
\hline
\end{tabular}

a. R Squared $=, 791$ (Adjusted R Squared $=, 704$ )

* = significantly different at $p<0.05$

Result the ANOVA test (table 2), showed the significantly mean differences $(p<0.05)$ of thermal changes for each of speed at distance 1 and $2 \mathrm{~mm}$ from drilling hole. 


\section{DISCUSSIONS}

In the process of odontectomy and preparation of dental implant in order to gain direct access to insert the implant, pin, or to remove embedded tooth, the use of bone drill may increase temperature around drilling hole. As thermal changes are critical primary precursor to primary physiological bone healing, increasing bone temperature around drilling site is the major concern in this research. The aim of this model study was to compare the temperatures that were generated with various speeds during bone drilling. In this study, twist drill bur was used as this type was commonly used (Karmani S., 2006).

In contrast to several previous studies, this study showed that temperature rise decreased with speed with the constant force. This can be explained that the main cause for increase in bone temperature is dependent upon the frictional forces and shearing forces at the cutting edges.

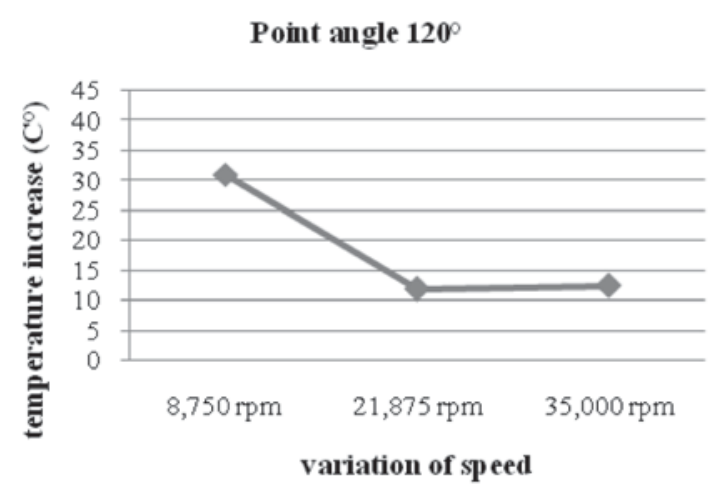

Graphic 3.

The pattern of thermal changes

Graphic 3 show that there was minimally temperature changes during bone drilling with speed $35000 \mathrm{rpm}$. At high speed drilling, the bur will penetrate by cutting and more efficiently remove bone chip away. Removal bone chip tend to decrease bone temperature. Increasing speed of penetration will tend to decrease drilling time. Drilling time is related with the friction and shear force. Shorter drilling time leads to an overall decrease in friction and shear force. The results of this study indicate that at high speed the drilling time is important factor in influential thermal changes the bone.

The bur bit point angle has a very high influence on the axial force. The point angle is calculated of the sum of $\phi$ and $\theta$ (Figure 4) (Fugelso, 2001).

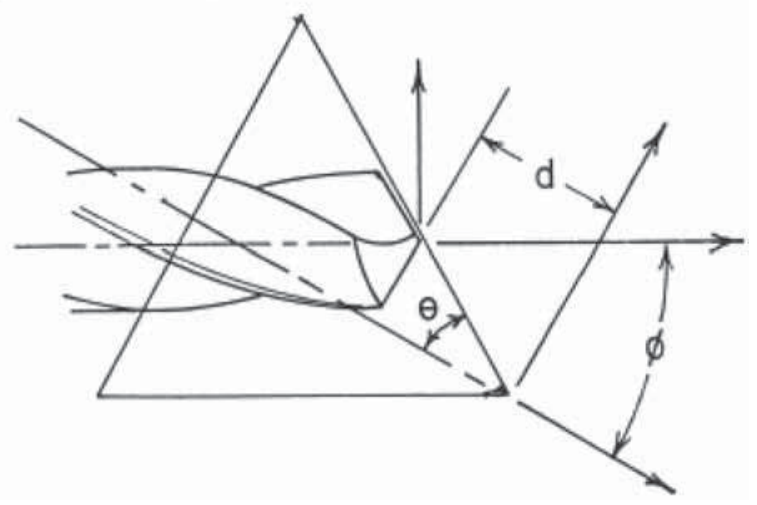

Figure 4.

Schematic drawing of bur bit point angle

Bur bit point angle is important and there is no agreement on which offers the best result. Theory predicts that a split point will reduce friction and that a quick helix is needed to clear the bone debris efficiently (Natali et. al., 1995).

Heat generation is major concern in several studies and the data that resulted from those studies shown that thermal damage is important factors. Clinical benefit that needs to be considered is injury through heat had to be carefully controlled to avoid impaired bone healing. Another important factor is cutting edge of drill bit. New drill bits which had drilled more than 200 holes, showed sign of blunting of the cutting edges. The worn drill showed greater temperature rise and longer duration of temperature elevation. (Abuzgia M.B., and Symington J.M., 1996)

The heat generated during bone surgery resulted from the drilling process. Shear stress by bur cutting surface on the bone surface layer will breaks intermolecular bonds and 
releasing energy (Karmani S., 2006). Bone has an internal energy that is derived as the sum of the molecular kinetic energy, the molecular potential energy and other kinds of molecular energy (Cutnell J.D., and Johnson, K.W., 2007).

Heat is transfered to bone material via three different mechanisms, i.e.: conduction, convection, and radiation. The major mechanism of bone heat transfers is via conduction which is occurred due to the shear stress between the surface of bur material and bone (Cutnell J.D., and Johnson, K.W., 2007).

Bone is anisotropic material and can be defined thermologically by certain parameters: (1) Specific heat capacity and (2) Thermal conductivity. Specific heat capacity represents the energy that required raising the temperature of the system by $1^{\circ} \mathrm{C}$. Equation 1 shows the relationship between heat $(\mathbf{Q})$, the change in temperature and to the mass (m), c is the specific heat capacity of the substance.

$Q=c m \Delta T \ldots \ldots(1)$

The second factor is thermal energy that represents the ability of a material to transport heat. The equation below show relationship between heat $(\mathbf{Q})$ that is conducted during time $t$ through the Length $L$ and crosssectional area $A$, is the temperature difference between the ends of bar and $k$ is the thermal conductivity of the material (Cutnell J.D., and Johnson, K.W., 2007).

$$
Q=\frac{(K A \Delta T)}{L} \cdots
$$

The equations above showed that the temperature developed within a section of bone tissue depends on specific heat capacity and thermal conductivity. These two properties permit bone to transfer heat around surrounding area.

\section{CONCLUSSION}

Control of bur speed rotation is important parameters to avoid rising bone temperature during bone drilling. Bone is anisotropic material and poor conductor. Temperature rise can be significantly having the potential risk of thermal damage during surgery.

\section{BIBLIOGRAPHY}

Abuzgia M. B. and Symington J.M., 1996, Effect of Drill Speed on Bone Temperature, J. Oral Maxillofac. Surg., 25, 394-399.

Cutnell J.D. and Johnson K.W., 2007, Physic, $7^{\text {th }}$ Edition. USA: John Willey \& Sons, Inc.

Fugelso, M.A., 2001, "A standard conical point drill grinding machine." Int. J. of Machine Tools \& Manufacture, 41, 915-922.

Hillery M.T. and Shuaib I., 1999, “Temperature effects in the drilling of human and bovine bone." J. of Material Processing Technology, 92-93, 302- 308.

Karmani S., 2006, "The thermal properties of bone and the effects of surgical intervention." Current Orthopaedic, 20, 52-58.

Leunig M. and Hertel R., 1996, “Thermal Necrosis after Tibial Reaming for Intramedullary Nail Fixation: A report of three cases," J.Bone Joint Surg., 78- B, 584-7.

Martini F., 2007, Fundamental of anatomy and Physiology, $7^{\text {th }}$ Ed., San Fransisco: Benjamin cummings.

Natali C., Ingle P., and Dowell J., 1996. "Orthopaedic Bone Drill-Can They be Improved?" J.Bone Joint Surg. (Br), 78-B, $357-62$.

Ohashi H., Therin M., and Meunier A., 1984, "Christel P., The effect of drilling parameters on bone," J. of materials science: material in medicine, 5, 225-231.

Schemitsch, E.H., Kowalski, M.J., Swiontkowski, M.F., Harrington, R.M., 1995, "Comparison of the effect of reamed and undreamed locked intramedullary nailing on blood flow in the $\mathrm{c}$ a $11 \mathrm{u} \mathrm{s}$ and strength of union following fracture of the sheep tibia," J. Orthop Res., 13, 3829. 